\title{
STATUS AND DIVERSITY OF SNAKES (REPTILIA: SQUAMATA: SERPENTES) At the Chittagong University Campus in Chittagong, BANGLADESH
}

\author{
M.F. Ahsan ${ }^{1}$, I.K.A. Haidar ${ }^{2}$ \& M.M. Rahman ${ }^{3}$ \\ ${ }^{1}$ Professor, ${ }^{2,3}$ Student, Department of Zoology, University of Chittagong, Chittagong 4331, Bangladesh \\ ${ }^{1}$ faridahsan55@yahoo.com (corresponding author), ${ }^{2}$ ibrahimalhaidar88@gmail.com, ${ }^{3}$ op.mizanepu@gmail.com
}

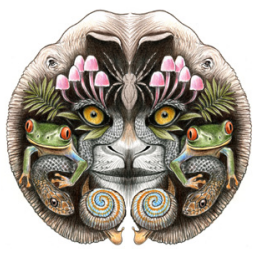

ISSN 0974-7907 (Online) ISSN 0974-7893 (Print)

OPEN ACCESS
Abstract: A study was conducted on the status and diversity of snakes of the Chittagong University Campus (CUC) between September 2013 and December 2014, and on preserved snake specimens of museums of CUC (Department of Zoology, University of Chittagong; Institute of Marine Sciences and Fisheries, University of Chittagong; and Institute of Forestry and Environmental Sciences, University of Chittagong). Thirty-six species of snakes belonging to 22 genera and five families (Typhlopidae, Pythonidae, Colubridae, Elapidae and Viperidae) were recorded from CUC during the study period. Colubridae comprised the highest (24 species i.e., 66.67\%) number of species and Pythonidae the lowest (1 species). Checkered Keelback Xenochrophis piscator was the most common snake and the rarest was the Bengalese Kukri Snake Oligodon dorsalis belonging to the family Colubridae. Among venomous snakes Banded Krait Bungarus fasciatus was the most common snake and Black Krait Bungarus niger was the most rare. Their status in CUC has been assessed.

Keywords: Bangladesh, Chittagong University Campus, diversity, snake, status.
Most of the snakes are harmless and even beneficial to humans and to the natural ecosystem. They are good friends of farmers and help in maintaining the ecological balance. Snakes are found all over the world except the Arctic Region, New Zealand and Ireland (Goin \& Goin 1971). There are about 3,496 species of snakes under 26 families around the world (Uetz \& Hošek 2015).

Snakes of Bangladesh are still poorly known. Sarker (1975) identified 21 species of snakes from the preserved specimens in the museums of the Department of Zoology, University of Dhaka and Rajshahi. These specimens were collected from Dacca (Dhaka), Tangail, Faridpur, Pabna, Rajshahi, Chittagong and Chittagong Hill Tracts Districts. Husain (1977) compiled a list and confirmed 40 species of snake are found in Bangladesh. Montaquim (1979) collected 48 specimens from
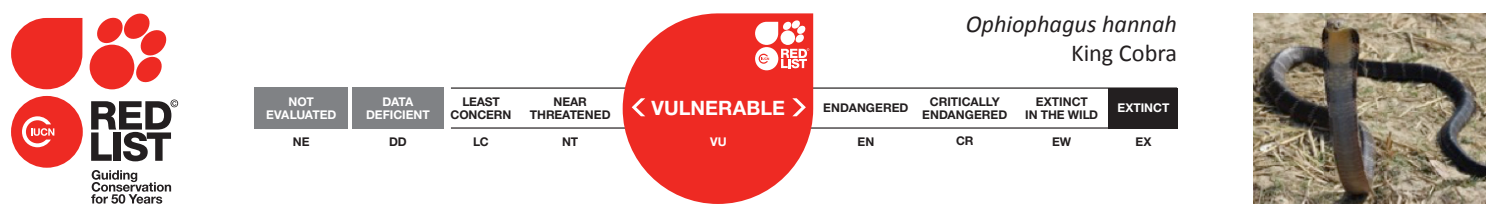

DOI: http://dx.doi.org/10.11609/jott.2431.7.14.8159-8166 | ZooBank: urn:Isid:zoobank.org:pub:7E86E3F5-8C0C-4E94-9C5C-84899F049A03

Editor: Raju Vyas, Vododara, Gujarat, India

Date of publication: 26 November 2015 (online \& print)

Manuscript details: Ms \# 04204 | Received 21 December 2014 | Final received 05 October 2015 | Finally accepted 27 October 2015

Citation: Ahsan, M.F., I.K.A. Haidar \& M.M. Rahman (2015). Status and diversity of snakes (Reptilia: Squamata: Serpentes) at the Chittagong University Campus in Chittagong, Bangladesh. Journal of Threatened Taxa 7(14): 8159-8166; http://dx.doi.org/10.11609/jott.2431.7.14.8159-8166

Copyright: (C Ahsan et al. 2015. Creative Commons Attribution 4.0 International License. JoTT allows unrestricted use of this article in any medium, reproduction and distribution by providing adequate credit to the authors and the source of publication.

Funding: Chittagong University Bird Club (CUBC).

Conflict of Interest: The author declares no competing interests.

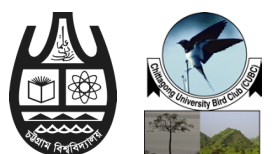

Acknowledgements: We would like to gratefully acknowledge Mr. Jadab Kumar Biswas, Assistant Professor; Mr. Rajib Acharjee, Lecturer; and Mr. Mohammad Abdul Wahed Chowdhury, Assistant Professor; Department of Zoology, University of Chittagong, Chittagong; M. Tarik Kabir and M. Manirul Islam, Wildlife and Biodiversity Conservation Officer Rajshahi and Khulna divisions respectively for their cordial help and suggestions during the study. We are also thankful to Afzal Hossain, Md. Ariful Islam, Md. Torikul Islam, Ferdaous Alam, Farzana Rahman, Nusrat Jahan Tania, Priyanka Rani Banick, Suravi Ahmed, Anwar Hossen and Kalyan Mondal for their participation and cooperation during the field study. We gratefully acknowledge all members of the Chittagong University Birds Club (CUBC) for their cordial support. 
different parts of Bangladesh (Pabna, Faridpur, Jessore, Kusthia, Jamalpur, Sylhet, Dhaka, Tangail, Chittagong, Chittagong Hill Tracts and some parts of the Bay of Bengal) and reported 18 species of snakes. Later Montaquim et al. (1980) compiled the previous records and reported 28 species of snakes from Bangladesh. Rashid (1982) collected 47 specimens from Chittagong, Chittagong Hill Tracts, Dhaka, Comilla, Faridpur, Khulna, Mymensingh, Sylhet, Tangail and the Bay of Bengal and reported 27 species of snakes. Khan (1982) annotated a list of snakes and accounted 78 species for the country. Sarker \& Sarker (1985) also compiled the records and reported 72 species of snakes from the country. Khan (1987) compiled the snake species again and reported 79 species. Sarker \& Sarker (1988) also reported 88 species of snakes from Bangladesh. Later, Khan (1992) reported 81 species of snakes in Bangladesh updating his previous list. Subsequently, Sarker \& Hossain (1997) reported 25 species from the costal islands of Bangladesh. Ahsan (1998) compiled the herpetofauna of Bangladesh and reported 77 species of snakes. Asmat \& Hannan (2007) annotated 94 species of snakes from Bangladesh. Khan (2008) accounted for 98 species of snakes in his compiled list including 13 unconfirmed ones. Kabir et al. (2009) listed 91 species from Bangladesh under six families and 46 genera. Khan (2010) also reported 94 species of snakes from Bangladesh.

No systematic study on snakes of the Chittagong University Campus (CUC) is on record, so an attempt was made to do some preliminary work on snakes. Parvin (1999) reported 41 species of snakes from Chittagong region based on the preserved specimens of the verified museums of some pronounced institutions and she mentioned 23 species of snakes with CUC as the location.

\section{STUdY AREA}

CUC (Fig. 1) is situated at Zubra Village under Fatehpur union parishad of Hathazari upazila (subdistrict) in Chittagong District, Bangladesh (22 $27^{\prime} 30^{\prime \prime}$ $22^{\circ} 29^{\prime} 0^{\prime \prime} \mathrm{N} \& 91^{\circ} 46^{\prime} 30^{\prime \prime}-91^{\circ} 47^{\prime} 45^{\prime \prime} \mathrm{E}$; area $7.10 \mathrm{~km}^{2}$ ). It is about $22 \mathrm{~km}$ north of the Chittagong City, $3 \mathrm{~km}$ southwest of Hathazari upazila headquarters and about $6 \mathrm{~km}$ east from the Bay of Bengal. CUC is surrounded by hills of Chittagong hill region and bisected by a small stream. It is decked with about $72 \%$ hills, lakes, ponds and plains and the valleys are $15.9 \mathrm{~m}$ above sea level (Islam et al. 1979). The soil of CUC is acidic in nature, $\mathrm{pH}$ is lower than 5.5 and texture varies from sandy loam to clayey loam; therefore the water holding capacity in the soil is very poor (Islam et al. 1979).

There are three seasons in CUC like elsewhere in
Bangladesh (Ahmad 1968): Summer (March-May), Rainy (June-October) and Winter (November-February). The University area enjoys a tropical climate characterized by hot and humid monsoon, and cool and dry winter. About $60 \%$ land area of CUC is covered by steep and very steep hills (Hossain et al. 2013); although it is composed of hills, valleys and plains.

\section{METHODS}

The study was conducted in CUC between September 2103 and December 2014. The study on preserved snake specimens of the museums of CUC (Department of Zoology, University of Chittagong [DOZ, CU]; Institute of Marine Sciences and Fisheries, University of Chittagong [IMSF, CU]; and Institute of Forestry and Environmental Sciences, University of Chittagong [IFES, CU]) was also carried out during the study period to know previously recorded snakes in CUC. Field observations were done throughout day and night but emphasis was given to night and morning when snakes are more active than other times, to find the snakes in their natural habitat. Opportunistic findings of snakes have also been included in the list. The whole study area was divided into six sites for convenience of the study (Fig. 1) and each site was further divided into two sub-sites to observe as diurnal and nocturnal sessions.

Site A (1): Comprised Shah Amanat Hall, Shah Jalal Hall, Faculty of Business Administration, northern portion of Kata Pahar and adjacent areas.

(2): Composed of Zero Point, Shaheed Minar, southern portion of Kata Pahar, Deshnetri Begum Khaleda Zia Hall, Shamsunnahar Hall, Pritilata Hall, University Club and a part of the Teachers' quarters.

Site B (1): Consisted of Sohrawardi Hall, Security Office, Central Mosque and adjacent areas.

(2): Contained Alaol Hall, F. Rahman Hall, Law Faculty, Medical Center, University Collage, and Old Shamsunnahar Hall, Officers' quarters, Pagoda and adjacent areas.

Site C (1): Comprised Central Field, University Press, Medical Colony and adjacent areas.

(2): Consisted of Social Science Faculty, Tele Hill, Probashi Colony, Shaheed Abdur Rab Hall and Bangabandhu Hall.

Site D (1): Consisted of Tangail Colony, Arts faculty, west and northern sides of Arts Faculty, water fall and adjacent areas.

(2): Composed of Arts Faculty Jhupri, Science Faculty and adjacent areas.

Site E (1): Comprised Institute of Marine Sciences and Fisheries, Faculty of Biological Sciences, Hill Bottom 


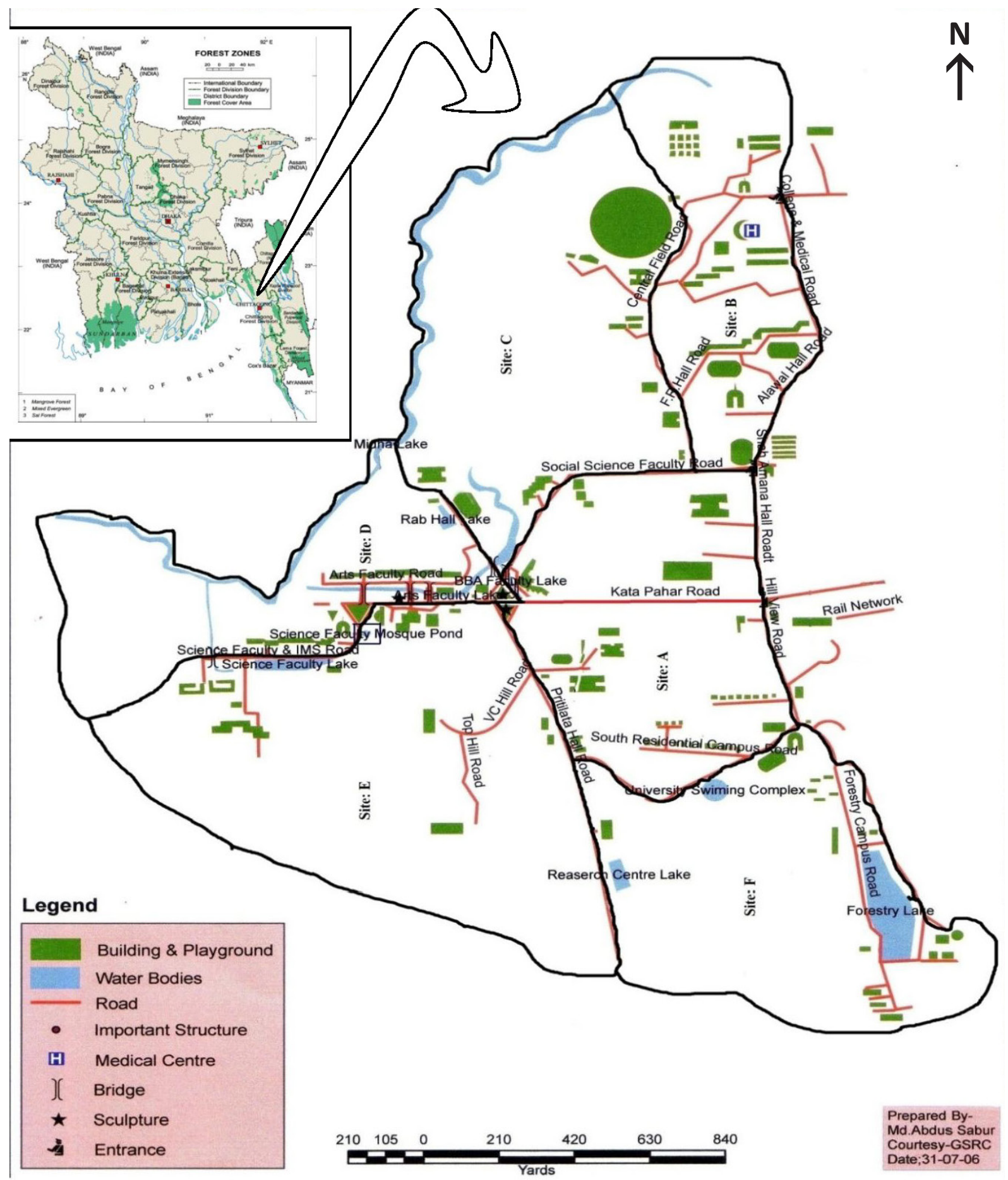

Figure 1. University of Chittagong - Campus map

Colony and surrounding areas.

(2): Composed of Central Library, IT building, VC Hill, Islamia Colony and Botanical Garden.

Site $F(1)$ : Consisted of RCMPS, Gol Pukur, South Campus forest region and South Campus lakes.

(2): Included an area with southern Campus Mosque,
Teachers' Quarters and Institute of Forestry and Environmental Sciences (IFESCU).

The snakes that are considered very common (VC), were those observed more than 15 times $(>75 \%$, of the total observation days), common (C) were seen 10-14 times (50-74\%, of the total observation days), fairly 
common (FC) were spotted 5-9 times (25-49\% of the total observation), uncommon (UC) were noticed 1-4 times (1-24\%, of the total observation days); and no sighting of the snakes in the field but found only in the museum as preserved specimens which are previously collected from CUC also listed in this list as rare species.

\section{RESULTS}

Thirty-six species of snakes (Table 1 ) belonging to 22 genera under five families were recorded from CUC during the study period (Images 1-21). Of which 24 species (66.67\%) were sighted during the field study but 27 species (75\%) were recorded from the museums as preserved specimens collected from the CUC (Images

Table 1. List of snakes of the Chittagong University Campus, Bangladesh.

\begin{tabular}{|c|c|c|c|c|c|}
\hline & Family & Scientific name & Common name & Status (CUC) & Museum voucher No. \\
\hline 1 & Typhlopidae & Ramphotyphlops braminus & $\begin{array}{l}\text { Common Worm Snake, Brahminy } \\
\text { Blind Snake }\end{array}$ & $\mathrm{R}$ & $81 \mathrm{CU}^{*}$ \\
\hline 2 & Typhlopidae & Argyrophis diardii & Diard's Blind Snake & UC & $32 \mathrm{CU}, 33 \mathrm{CU}, 78 \mathrm{CU}$ \\
\hline 3 & Typhlopidae & Typhlops jerdoni & Jerdon's Blind Snake & UC & \\
\hline 4 & Pythonidae & Python bivittatus & Burmese Python & $\mathrm{FC}$ & \\
\hline 5 & Colubridae & Ahaetulla nasuta & $\begin{array}{l}\text { Common Whip Snake, Common } \\
\text { Vine Snake }\end{array}$ & C & $74 \mathrm{CU}$ \\
\hline 6 & Colubridae & Ahaetulla prasina & Short-nosed Vine Snake & UC & $12 \mathrm{CU}, 52 \mathrm{CU}, 113 \mathrm{CU}$ \\
\hline 7 & Colubridae & Amphiesma stolatum & Striped Keelback & UC & $86 \mathrm{CU}, 87 \mathrm{CU}$ \\
\hline 8 & Colubridae & Atretium schistosum & Olive Keelback & $\mathrm{R}$ & $95 \mathrm{CU}$ \\
\hline 9 & Colubridae & Boiga cyanea & Green Cat Snake & UC & \\
\hline 10 & Colubridae & Boiga cynodon & Bengal Cat Snake & $\mathrm{R}$ & $120 C U$ \\
\hline 11 & Colubridae & Boiga gokool & Eastern Cat Snake & $\mathrm{R}$ & IFESCU04** \\
\hline 12 & Colubridae & Boiga ochracea & Tawny Cat Snake & UC & \\
\hline 13 & Colubridae & Chrysopelea ornata & Ornate Flying Snake & UC & \\
\hline 14 & Colubridae & Coelognathus radiatus & Copper-headed Trinket Snake & FC & $62 \mathrm{CU}$ \\
\hline 15 & Colubridae & Dendrelaphis pictus & Painted Bronze-back Tree Snake & FC & \\
\hline 16 & Colubridae & Dendrelaphis tritis & Common Bronze-back Tree Snake & C & $8 \mathrm{CU}, 54 \mathrm{CU}$ \\
\hline 17 & Colubridae & Enhydris enhydris & Common Smooth Water Snake & $\mathrm{R}$ & $47 \mathrm{CU}$ \\
\hline 18 & Colubridae & Lycodon aulicus & Common Wolf Snake & VC & $83 \mathrm{CU}$ \\
\hline 19 & Colubridae & Lycodon jara & Yellow-speckled Wolf Snake & $\mathrm{R}$ & $82 \mathrm{CU}$ \\
\hline 20 & Colubridae & Oligodon albocinctus & White-barred Kukri Snake & $\mathrm{R}$ & $84 C U$ \\
\hline 21 & Colubridae & Oligodon cyclurus & Cantor's Kukri Snake & UC & \\
\hline 22 & Colubridae & Oligodon dorsalis & $\begin{array}{l}\text { Bengalese Kukri Snake, Spot-tailed } \\
\text { Kukri Snake }\end{array}$ & $\mathrm{R}$ & $61 C U$ \\
\hline 23 & Colubridae & Psammodynastes pulverulentus & Mock Viper & UC & \\
\hline 24 & Colubridae & Ptyas korros & Indo-Chinese Rat Snake & VC & $103 \mathrm{CU}, 104 \mathrm{CU}$ \\
\hline 25 & Colubridae & Ptyas mucosa & Indian Rat Snake & C & $101 \mathrm{CU}$ \\
\hline 26 & Colubridae & Rhabdophis subminiatus & Red-necked Keelback & FC & $88 \mathrm{CU}$ \\
\hline 27 & Colubridae & Xenochrophis flavipunctatus & Checkered Keelback & VC & $13 \mathrm{CU}, 89 \mathrm{CU}$ \\
\hline 28 & Colubridae & Xenochrophis flavipunctata & Yellow-spotted Keelback & $\mathrm{R}$ & $94 \mathrm{CU}$ \\
\hline 29 & Elapidae & Bungarus caeruleus & Common Krait & $\mathrm{R}$ & $124 C U$ \\
\hline 30 & Elapidae & Bungarus fasciatus & Banded Krait & VC & $67 \mathrm{CU}$ \\
\hline 31 & Elapidae & Bungarus niger & Black Krait & $\mathrm{R}$ & $81 \mathrm{bCU}$ \\
\hline 32 & Elapidae & Naja kaouthia & Monocellate Cobra, Monocled Cobra & C & $30 \mathrm{CU}, 70 \mathrm{aCU}, 72 \mathrm{CU}$ \\
\hline 33 & Elapidae & Naja naja & Binocellate Cobra, Spectacled Cobra & UC & $68 \mathrm{CU}$ \\
\hline 34 & Elapidae & Ophiophagus hannah & King Cobra & UC & $58 \mathrm{CU}, 60 \mathrm{CU}, 76 \mathrm{CU}, 77 \mathrm{CU}$ \\
\hline 35 & Viperidae & Trimeresurus albolabris & White-lipped Tree Viper & C & \\
\hline 36 & Viperidae & Trimeresurus erythrurus & Spot-tailed Pit Viper & $\mathrm{R}$ & $34 \mathrm{CU}, 35 \mathrm{CU}, 137 \mathrm{CU}$ \\
\hline
\end{tabular}

CUC - Chittagong University Campus; * DOZ, CU - Department of Zoology, University of Chittagong; ** IFES, CU - Institute of Forestry and Environmental Sciences, University of Chittagong. 
22-24). Among the recorded species 15 (i.e., 41.67\%) were found both in the field and museums; 12 were found in the museums and nine were observed during field study.

Among the 36 species of snakes, three species (8.33\%) belong to the family Typhlopidae, one species $(2.78 \%)$ of Pythonidae, 24 species (66.67\%) of Colubridae, six species (16.67\%) of Elapidae and two species (5.56\%) of Viperidae. The total recorded species are $87.80 \%$ compared to the Chittagong region (41 species: Parvin 1999) and 39.56\% snakes of Bangladesh (91 species: Kabir et al. 2009). Four species (11.11\%) of snakes are very common, five species $(13.89 \%)$ are common, nine species (25\%) are fairly common, six species (16.67\%) are uncommon; and 12 species (33.33\%) are rare in the CUC. Overall, Checkered Keelback Xenochrophis piscator is the most common, and Bengalese Kukri Snake Oligodon dorsalis is the rarest snake. There are only eight species $(22.22 \%$ of the total snakes of CUC) of venomous snakes occurring in CUC; six species (75\%) under three genera (Bungarus, Naja and Ophiophagus) belong to the family Elapidae and two species (25\%) under one genus (Trimeresurus) to Viperidae. Among them Banded Krait Bungarus fasciatus is the most common. Except three semi-aquatic species (Xenochrophis piscator, $X$. flavipunctata and Enhydris enhydris) all the snakes found in CUC are terrestrial.

Further studies are needed to know the detailed ecology of the snakes that inhabit CUC. Habitat is being destroyed due to the collection of litter and the cutting of shrubs for fuel by the local people. Furthermore, human settlements in the valleys and in the bottom of the hills, aquaculture in the re-excavated water bodies and agricultural practices are also destroying the habitat of the snakes. All the above factors are causing unsustainable diversity of snakes, so we need to minimize the problems for future sustainable development of snake diversity in CUC.

\section{REFERENCES}

Ahmad, N. (1968). An Economic Geography of East Pakistan. Oxford University Press, Oxford, 401pp.

Ahsan, M.F. (1998). Country reports for Bangladesh - Herpetofauna of Bangladesh: present status, distribution and conservation, pp.
9-17. In: Biology and Conservation of the Amphibians, Reptiles and Their Habitats in South Asia. (Silva, A de eds.). Proceedings of the International Conference on the Biology and Conservation of the Amphibians and Reptiles of the South Asia, Sri Lanka, August 1-5, 1996. Amphibia and Reptile Research Organization of Sri Lanka, Kandy.

Asmat, G.S.M. \& M.A. Hannan (2007). Checklist of Wild Animals of Bangladesh. Gazi Publishers, Dhaka, 292pp.

Goin, J.C. \& O.B. Goin (1971). Introduction to Herpetology - $2^{\text {nd }}$ Edition. W. H. Freeman \& Company, San Francisco, 353pp.

Hossain, M.S., S. Muhammad, A.A. Mamun \& S.M.S. Haque (2013) Patch weeding on success of plantation in Chittagong University. Bangladesh Research Publication Journal 9(2): 75-78.

Husain, K.Z. (1977). Bangladesher banayanjontu shampad O tar sangrakshan (Wild animals of Bangladesh and their conservation) (in Bengali). Bangla Academy Bijnan Patrica 3(3): 1-11.

Islam, A.T.N.T., H.S.S. Chowdhury, A.K.M.M. Hoque \& S.A. Malik (1979). Detailed Soil Survey Chittagong University Campus, Chittagong 1974 [Preliminary Edition (S.M. Saheed, (ed.))]. Department of the People's Republic of Bangladesh, Dacca. 207pp+iii.

Kabir, S.M.H., M. Ahmad, A.T.A. Ahmed, A.K.A. Rahman, Z.U. Ahmad, Z.N.T. Begum, M.A. Hassan \& M. Khondker (eds.) (2009). Encyclopedia of Flora and Fauna of Bangladesh - Vol. 25. Amphibians and Reptiles. Asiatic Society of Bangladesh, Dhaka, 204pp.

Khan, D.R. (2010). Wildlife of Bangladesh - A Checklist (from Amphibia to Mammalia with Bengali Names). Shahitya Prakash, Dhaka, 128pp.

Khan, M.A.R. (1982). Wildlife of Bangladesh - A checklist. The Dhaka University Press, Dhaka, $174 \mathrm{pp}$.

Khan, M.A.R. (1987). Bangladesher Banaya Prani (Wildlife of Bangladesh) - Vol. 1. (in Bengali) Bangla Academy, Dhaka, 169pp.

Khan, M.A.R. (1992). Bangladesher Shap (Snakes of Bangladesh) (in Bengali). Bangla Academy, Dhaka, 227pp.

Khan, M.M.H. (2008). Protected Areas of Bangladesh - A Guide to Wildlife. Nishorgo Program, Bangladesh Forest Department, Dhaka, 304pp.

Montaquim, M.A. (1979). Snakes of several districts of Bangladesh. MSc Thesis (Unpublished), University of Dhaka, Dhaka, 63pp+Vpls.

Montaquim, M.A., A.H. Sarkar, M.A.R. Khan \& K.Z. Husain (1980). List of the snakes of Bangladesh. Bangladesh Journal of Zoology 8(2): 127-129.

Parvin, S. (1999). On some snakes of Chittagong. MSc thesis (Unpublished) University of Chittagong, Chittagong, 188pp.

Rashid, S.M.A. (1982). On some snakes of Bangladesh with notes on their habit, habitat, status and distribution. MSc Thesis (Unpublished). University of Dhaka, Dhaka, xv+108pp.

Sarker, M.A.H. (1975). Snakes of Bangladesh. MSc Thesis (Unpublished). University of Dhaka, Dhaka, xii+70pp.

Sarker, M.S.U. \& M.L. Hossain (1997). Ecological study on the wildlife resources of coastal islands and their conservation. The Journal of Noami 14(1\&2): 39-54

Sarker, M.S.U. \& N.J. Sarker (1985). Reptiles of Bangladesh (with their status, distribution and habitat). Tigerpaper XII(2): 6-12.

Sarker, M.S.U. \& N.J. Sarker (1988). Wildlife of Bangladesh (A Systematic List with Status, Distribution and Habitat). The Rico Printers, Dhaka, 69pp.

Uetz, P. \& J. Hošek (eds.) (2015). The Reptile Database. http://www. reptile-database.org/db-info/SpeciesStat.html. Accessed on 31 August 2014. 


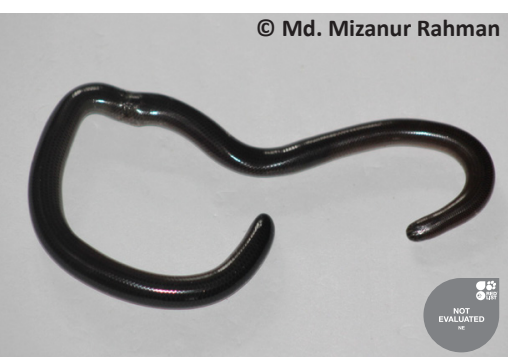

Image 1. Typhlops jerdoni Jerdon's Blind Snake

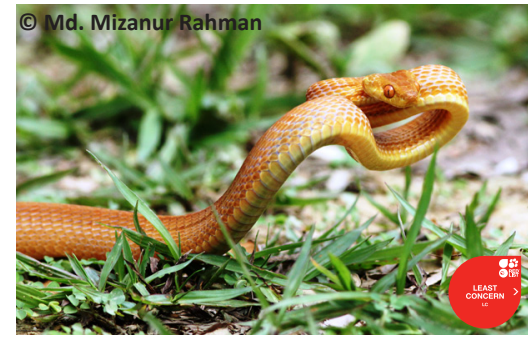

Image 4. Boiga ochracea Tawny Cat Snake

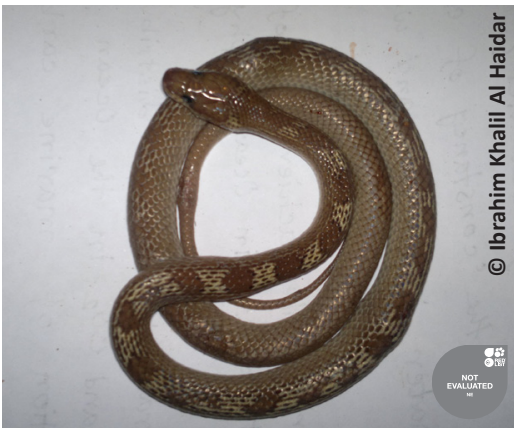

Image 7. Lycodon aulicus Common Wolf Snake

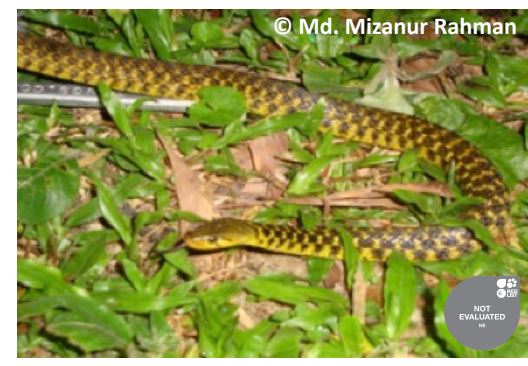

Image 10. Xenochrophis piscator Checkered Keelback

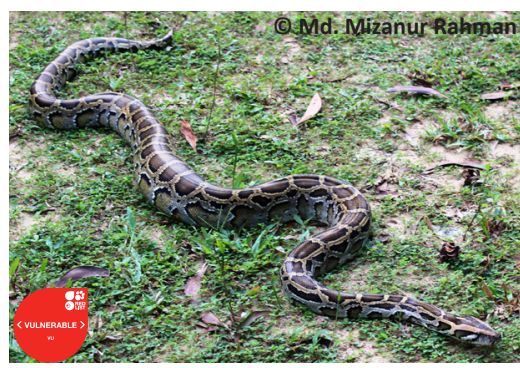

Image 2. Python bivittatus Burmese Python

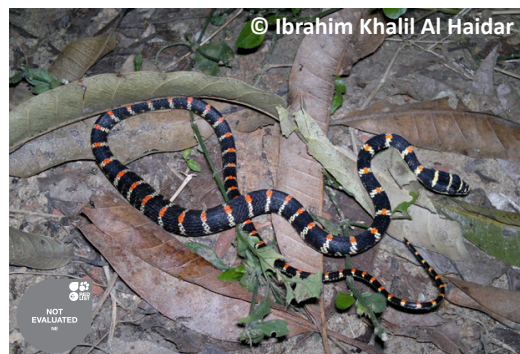

Image 5. Chrysopelea ornata Ornate Flying Snake

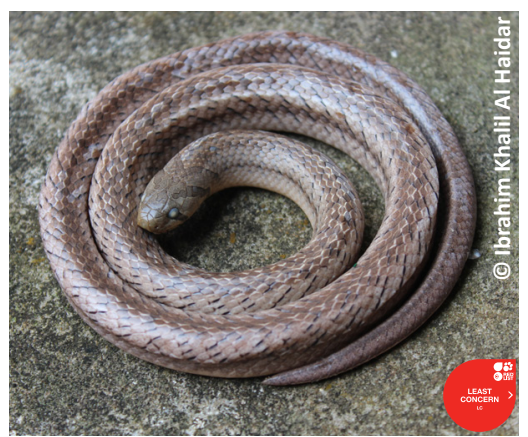

Image 8. Oligodon cyclurus Cantor's Kukri Snake

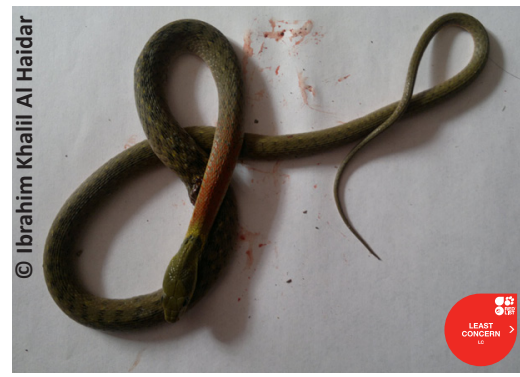

Image 11. Rhabdophis subminiatus Red-necked Keelback

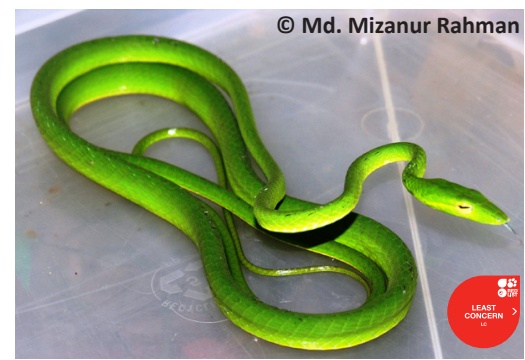

Image 3. Ahaetulla prasina Short-nosed Vine Snake

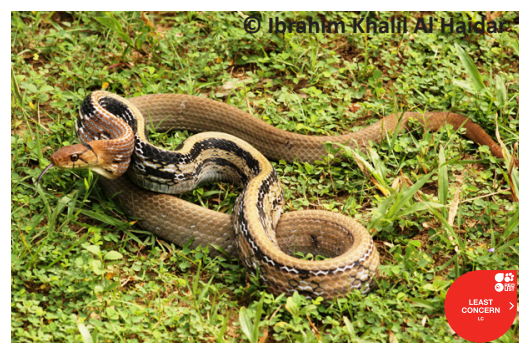

Image 6. Coelognathus radiatus Copperheaded Trinket Snake

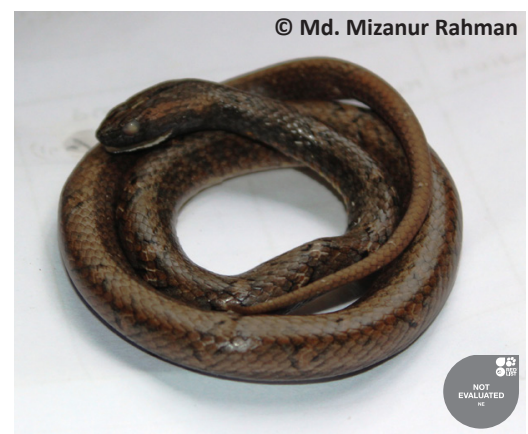

Image 9. Psammodynastes pulverulentus Mock Viper

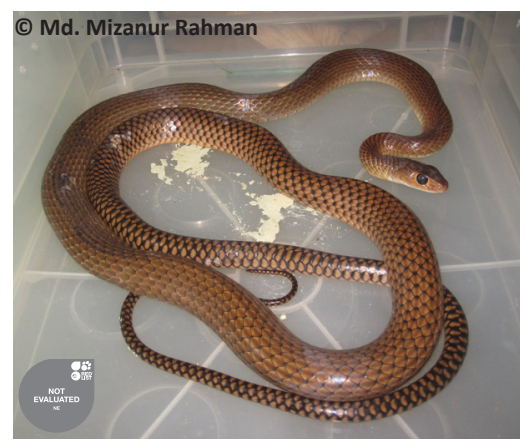

Image 12. Ptyas korros Indo-Chinese Rat Snake 


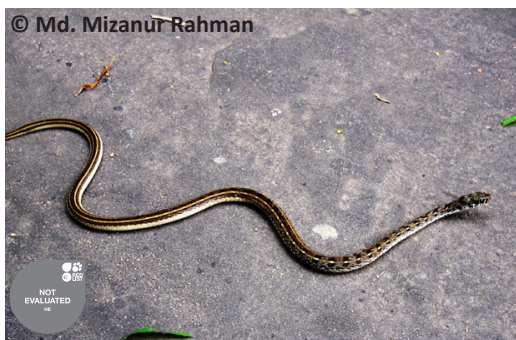

Image 13. Amphiesma stolatum Striped Keelback

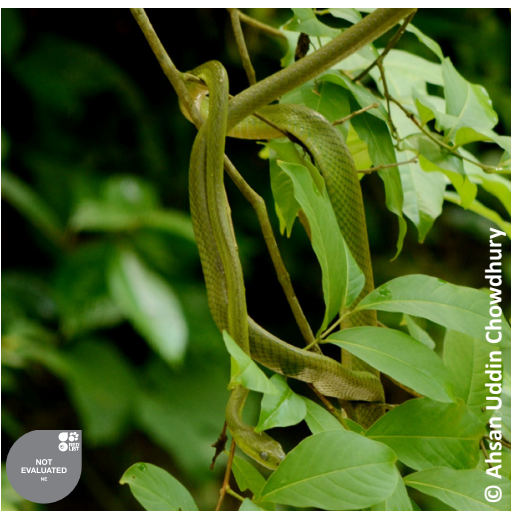

Image 16. Boiga cyanea Green Cat Snake

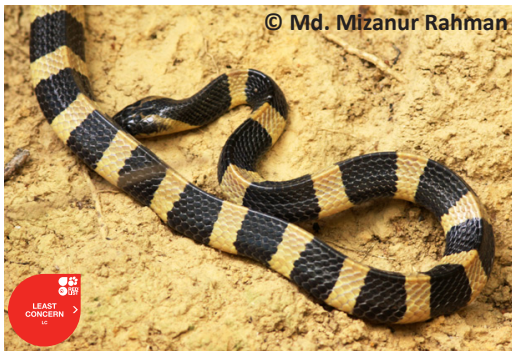

Image 19. Bungarus fasciatus Banded Krait

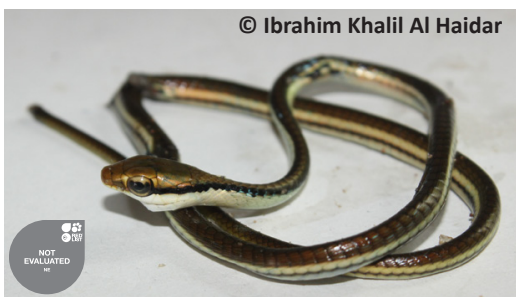

Image 14. Dendrelaphis pictus Painted Bronze-back Tree Snake

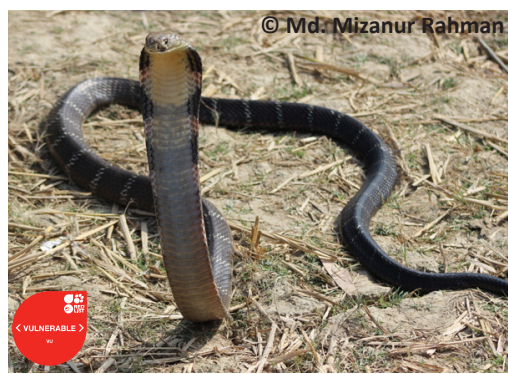

Image 17. Ophiophagus hannah King Cobra

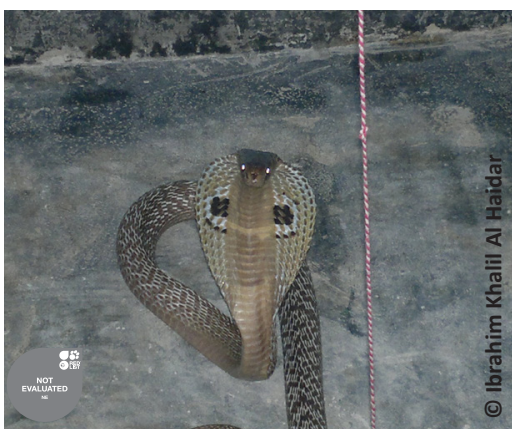

Image 20. Naja naja Spectacled Cobra

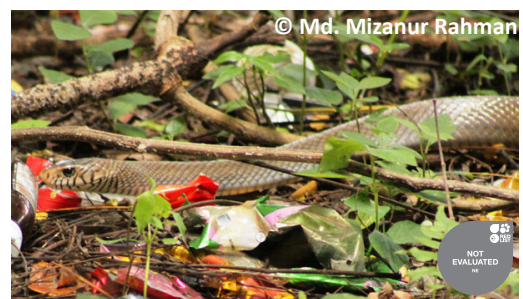

Image 15. Ptyas mucosa Indian Rat Snake

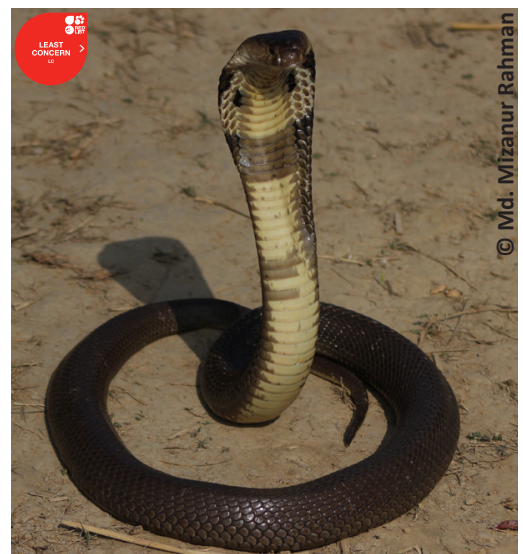

Image 18. Naja kaouthia Monocled Cobra

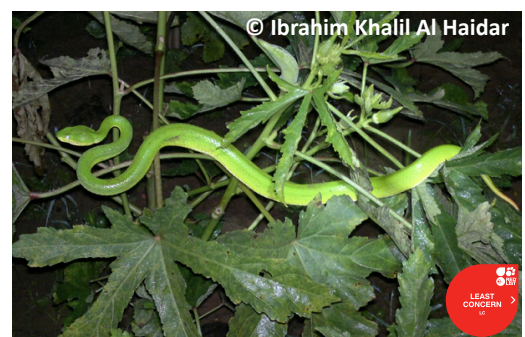

Image 21. Trimeresurus albolabris Whitelipped Tree Viper
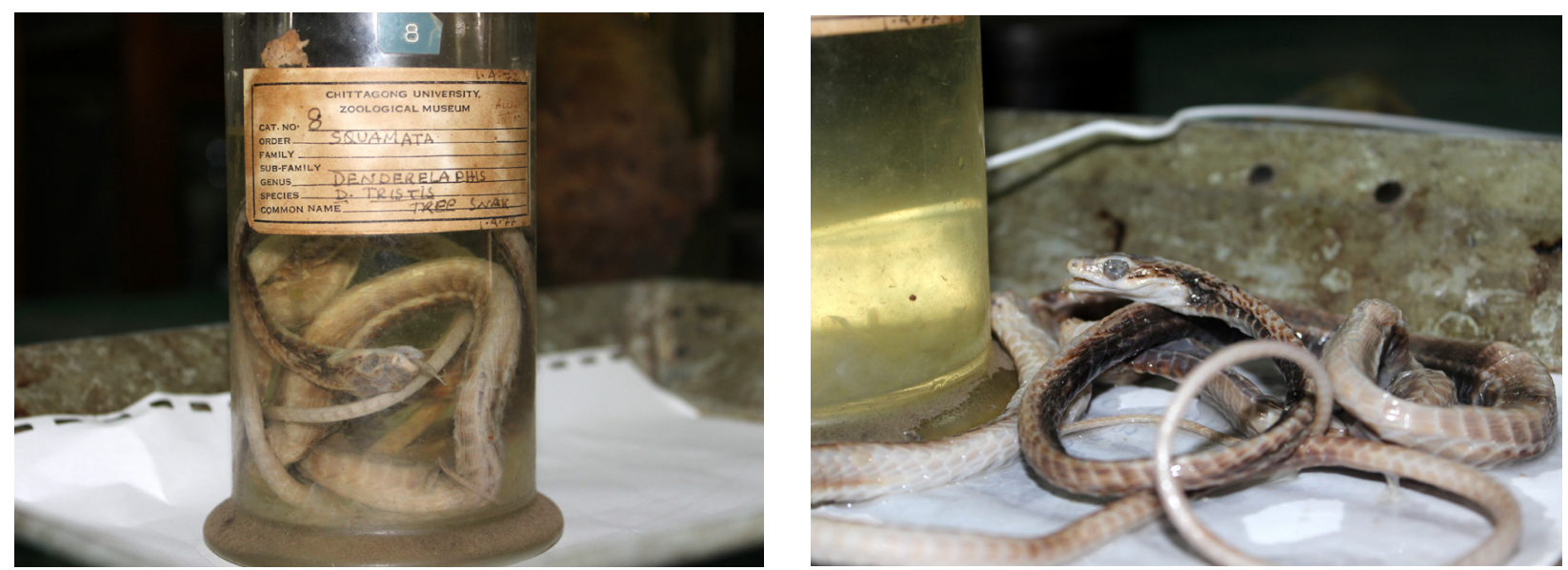

Image 22. Preserved specimens from the museum, Department of Zoology, University of Chittagong - Dendrelaphis tritis Common Bronzeback Tree Snake Voucher no. $8 \mathrm{CU}$ 

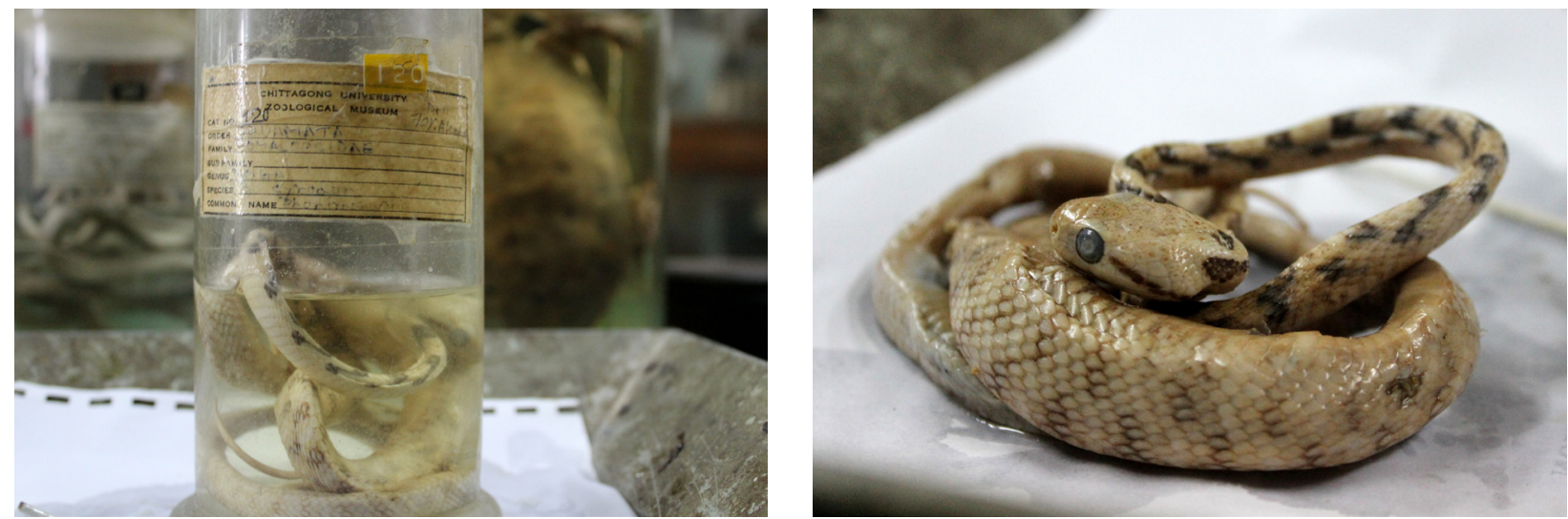

Image 23. Preserved specimens from the museum, Department of Zoology, University of Chittagong - Boiga cynodon Bengal Cat Snake Voucher no. 120CU
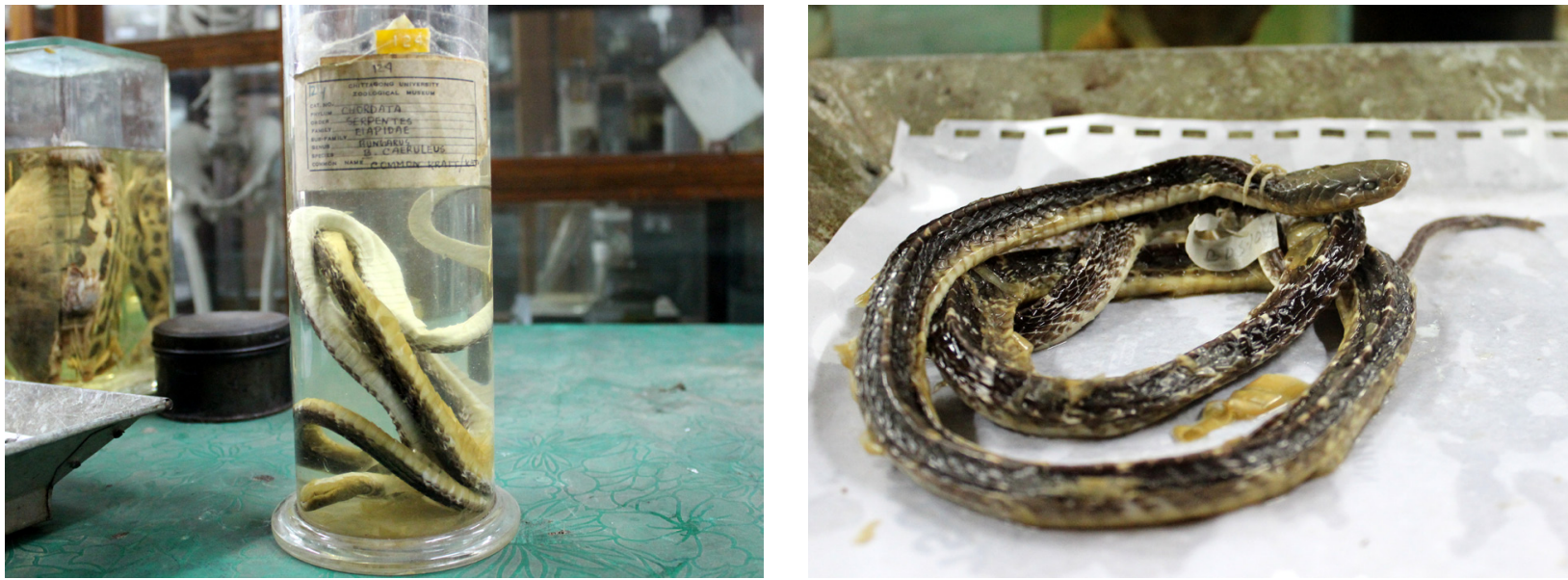

Image 24. Preserved specimens from the museum, Department of Zoology, University of Chittagong - Bungarus caeruleus Common Krait Voucher no. 124CU 